\title{
Mental Status Extrication (MSE)
}

\author{
I, poised on the edge \\ of reason, sway. \\ While you, weighing differentials, \\ strike a diagnostic match \\ igniting fiery thoughts and \\ cogitating a multi-axial symptom overload. \\ I, wording my life, flounder. \\ Gasp, a fish on the table. \\ You and I fray over \\ shattered mirrors reflecting only \\ I in mine and you in yours. \\ You ask about my mother. \\ She was there, but not where \\ I, could find a history \\ In the splayed shards that \\ You, compose into me \\ With an assertive air. \\ Pill purveyor, dream voyeur. \\ I have seen izangoma", priests, witchdoctors. \\ Did they see me? I cannot know. \\ You a doctor of Which? When? What? \\ Questions to throw my bones. \\ To read where they lie. \\ To determine my status of mind. \\ I rise unpatient-like and cross a canyon in bare feet, \\ encountering you midway, adrift. \\ You trying to put yourself in my shoes \\ You still in your own feet.
}

*South African Zulu diviners who use methods including the throwing of bone fragments to divine causes and treatments for physical, psychological and spiritual ailments.

\section{Thirusha Naidu}

Corresponding to: Thirusha Naidu, Department of Behavioural Medicine, University of KwaZulu-Natal, Durban, South Africa; Naidut10@ukzn.ac.za

Competing interests None.

Provenance and peer review Not commissioned; internally peer reviewed.

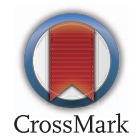

To cite Naidu Thirusha. Med Humanit 2015;41:e5.

Med Humanit 2015;41:e5. doi:10.1136/medhum-2014-010635 